\title{
ANALISIS KESULITAN MAHASISWA IPTS DALAM MENYELESAIKAN SOAL-SOAL TOEFL
}

\author{
oleh: \\ Lollo Rosa Lubis ${ }^{1)}$, Aprida Irmayana ${ }^{2)}$ \\ ${ }^{1}$ Fakultas IPSB, Institut Pendidikan Tapanuli Selatan \\ ${ }^{1}$ email:lollorosalubis@gmail.com \\ ${ }^{2}$ Fakultas IPSB, Institut Pendidikan Tapanuli Selatan \\ ${ }^{2}$ email:apridairmayana20@gmail.com
}

\begin{abstract}
Abstrak
Penelitian ini bertujuan untuk menggambarkan hasil TOEFL dan menganalisis skill yang paling sulit dirasakan oleh mahasiswa IPTS semester VIII tahun ajaran 2019/2020. Pendekatan yang digunakan dalam penelitian ini adalah deskriptif kualitatif dengan 40 mahasiswa sebagai sampel dan mereka diambil dengan menggunakan purposive sampling dari 96 mahasiswa. Selanjutnya tes dagnostik dan wawancara digunakan sebagai alat pengumpil data. Hasil penelitian menunjukkan bahwa Listening Coprehension adalah bagian tersulit dirasakan oleh mahasiswa diikuti oleh Structure and Written Expression dan Reading Comprehension. Selanjutnya di bagian Listening Comprehensioan tergambar bahwa long conversation adalah skill yang tersulit dirasakan oleh mahasiswa kemudian talking dan short conversation. Di bagian Structure and Written Expression tergambar bahwa structure merupakan skill yang paling sulit daripada written expression. Selanjutnya di bagian Reading Conprehension tergambar bahwa mengidentifikasi makna kata- kata sulit merupakan skil yang tersulit dirasakan oleh mahasiswa kemudian mengidentifikasi topik, kalimat penjelas, dan reference merupkan skill yang paling mudah dirasakan oleh mahasiswa di bagian Reading Comprehension.
\end{abstract}

Kata kunci: TOEFL, kesulitan

\section{PENDAHULUAN}

Lulus Test of English as Foreign Language (TOEFL) adalah salah satu syarat sebelum mengikuti yudisium di IPTS (Institut Pendidikan Tapanuli Selatan) dan hal ini diberlakukan sejak tahun 2014 (SK Rektor Nomor 050/SK.K/STKIP-TS/I/10/2014). Berdasarkan SK tersebut pula, dinyatakan bahwa mahasiswa IPTS khususnya program studi Pendidikan Bahasa Inggris dinyatakan lulus apabila mencapai skore minimal 450 dan jurusan lainnnya harus mencapai skore minimal 400. Apabila skore tersebut belum tercapai maka mahasiswa tersebut wajib mengikuti TOEFL kembali sampai peserta bisa mencapai skore minimum tersebut dan dinyatakan lulus. Kebijakan ini diberlakukan dalam rangka meningkatkan kualitas pendidikan di lingkungan IPTS dan membekali mahasiswa dengan kemampuan penguasaan Bahasa Inggris melalui kemampuan lulus TOEFL.

Berdasarkan data dari UPT Bahasa Inggris IPTS pada tahun 2018, 40\% mahasiswa mengalami kegagalan dalam menghadapi TOEFL. Dengan kata lain, hanya $60 \%$ mahasiswa yang sanggup mencapai score minimal dengan test 1 kali saja, selebihnya harus menghadapi test berkali-kali, bahkan banyak mahasiswa harus mendapatkan pelatihan khusus untuk mendapatkan score minimal tersebut. Keadaan ini menyebabkan mahasiswa tertunda untuk mengikuti yudisium dan pada akhirnya banyak mahasiswa tidak dapat lulus tepat waktu gara-gara tidak lulus TOEFL.

$\begin{array}{crrr}\text { Telah } & \text { banyak } & \text { penelitian } & \text { yang } \\ \text { menginvestigasi } & \text { beberapa } & \text { faktor } & \text { yang }\end{array}$

mempengaruhi keberhasilan dalam menghadapi TOEFL. Salah satu penelitian sebut adalah penelitian milik Heni Kartikasari dkk (2014) dengan judul "Analisis Regresi Multivariat Terhadap Penilian Listening, Structure, dan Reading pada Nilai Test EFL Mahasiswa ITS." Penelitian ini bertujuan untuk melihat hubungan yang signifikan antara nilai test EFL mahasiswa yang meliputi listening (Y1), structure (Y2), dan reading (Y3) dengan 12 varibel respon meliputi IPK (X1), IPS Semester 6 (X2), IPS Semester 7 (X3), Nilai Bahasa Inggris (X4), Lama Belajar (X5), nilai test EFL baru (X6), nilai test EFL awal (X7), nilai test EFL terahir (X8), frekuensi mengikuti test EFL (X9), skor aktivitas Listening (X10), skor aktivitas structure (X11), dan skor aktivitas Reading (X12). Hasil penelitian tersebut menunjukkan bahwa semua variable respon di atas memiliki hubungan yang lemah terhadap semua variable prediktor

Penelitian di atas cukup memberikan informasi bahwa TOEFL itu bukanlah test biasa tapi suatu yang test yang membutuhkan persiapan dan keseriusan dalam menghadapinya. Tapi sayang penelitian diatas tidak mengidentifikasi skill manakah yang paling sulit dirasakan oleh peserta dalam menghadapi TOEFL. Berdasarkan permasalahan di atas pula, penulis tertarik untuk melakukan investigasi pada mahasiswa jurusan Pendidikan Bahasa Inggris di IPTS 1) bagaimanakah gambaran hasil TOEFL dan 2) skill manakah yang paling sulit mereka rasakan dalam menyelesaikan soal-soal TOEFL. Penelitian ini dianggap penting karena sepengetahuan penulis 
belum ada peneliti yang mengidentifikasi hal di atas dengan menggunakan gabungan dua macam data meliputi data kuantitaif dan data kualitatif. Data kuantitif dikumpulkan dengan menggunakan test diagnostik sedangkan untuk menjaring data kualitatif, penulis menggunakan wawancara. Kedua macam data tersebut dianalisis dengan mengutamakan data kuantitatif apabila ada data yang bertentangan.

\section{METODE PENELITIAN}

Pendekatan yang dilakukan dalam penelitian ini adalah mix method dengan menerapkan the embedded design dengan menggabungkan data kualitatif dan kualittaif. Data kuantitatif diambil dengan menggunakan test diagnostik sedangkan data kualitatif diambil dengan menggunakan wawancara. Kedua jenis data ini dianalisis dengan mengutamakan data kuantitatif. Hal ini senada dengan penjelasan Creswell $^{10}$ (2012:544) yang mana sudah diartikan kedalam Bahasa Indonesia,'Tujuan penelitian embedded adalah mengumpulkan data kuantitatif dan kualitatif secara simultan atau berurutan, namun memiliki satu bentuk data yang sangat mendukung peran lain terhadap bentuk data lainnya" Sedangkan dalam pengambilan sample, penulis menggunakan purposive sampling technique. Sampel diambil sebanyak 40 orang dari 96 mahasiswa semester VIII tahun akademik 2019/2020.

Selanjutnya dalam tehnik pengumpulan data, penulis menggunakan test diagnostik dan wawancara. Test diagnostik diberikan dalam bentuk pilihan berganda yang terdiri dari tiga bagian meliputi Listening Comprehension (50 item soal), Structure and Writing Expression (40 item soal), dan Reading Comprehension (50 item soal). Jumlah keseluruhan test yang diberikan sebanyak 140 item. Hasil test ini dianalisis untuk mengetahui skill manakah yang paling sulit dihadapi sewaktu menyelesaikan soal-soal TOEFL, artinya skill yang memiliki rata-rata paling rendah dinyatakan sebagi skill yang paling sulit. Test ini dilakukan untuk menjaring data kuantitatif. Sedangkan wawancara dilakukan untuk mendukung data kuantitatif di mana semua peserta diberikan pertanyaaan secara lisan, skill manakah yang paling sulit mereka rasakan saat menyelesaikan TOEFL .

\section{HASIL DAN PEMBAHASAN}

Mengenai skill yang paling sulit dirasakan mahasiswa dalam menyelesaikan TOEFL akan dipaparkan terhadap 3 bagian yang meliputi Listening Comprehension, Structure and Written Expression, dan Reading Comprehesion. Adapun data yang dikumpulkan penulis menggunakan dua macam data yaitu data kuantitatif (test diagnostik) dan data kualitatif (wawancara).
1. Nilai rata-rata kemampuan mahasiwa dalam TOEFL

\begin{tabular}{|c|c|c|c|}
\hline 1 & 2 & 3 & 4 \\
\hline Rata -rata & 442 & 443 & 453 \\
\hline
\end{tabular}

Table. 1. Rata- rata TOEFL mahasiswa jurusan Pendidikan Bahasa Inggris

Ket: $\quad 1=$ Ukuran

$2=$ Listening Comprehension

$3=$ Structure and Written Expression

4=Reading Comprehension

Untuk mengetahui kategori yang diperoleh ada baiknya penulis memberikan gambaran berdasarkan Standar Internasional yang dirancang dan diolah dari Oxford Placement Test (Allan, 1992); IELTS Band Score (IELTS Handbook, 1999); dan LAN, ODA, BC, 1996). Untuk lebih jelas, kategori tersebut dapat dilihat dalam table berikut:

Table. 2. Kategori TOEFL

\begin{tabular}{|l|l|}
\hline $\begin{array}{c}\text { Rentang Skor } \\
\text { TOEFL }\end{array}$ & \multicolumn{1}{|c|}{ Kategori } \\
\hline $617-677$ & Near-Native Speaker/expert user \\
\hline $563-613$ & Professional User/highly proficient user \\
\hline $540-560-$ & Advanced/proficientuser \\
\hline $493-537$ & Post Intermediate/competent user \\
\hline $457-490$ & Upper Intermediate/ independent user \\
\hline $420-453$ & Lower Intermediate/ adequate user \\
\hline $377-417$ & Elementary/limited user/hreshold level \\
\hline $310-373$ & Basid/very limited user \\
\hline $263-307$ & Falsebeginner/minimal user \\
\hline $217-260$ & Absolute beginner/non-user \\
\hline
\end{tabular}

Berdasarkan table di atas, dapat dipaparkan bahwa rata-rata kemampuan mahasiswa dalam Listening Comprehension adalah 442 berada pada kategori adequate user. Selanjutnya Structure and Written Expression memiliki rata -rata 443 dan Reading Comprehension memiliki rata rata 453 berada pada kategori adequate user. Berdasarkan rata-rata, Listening Comprehension memiliki nilai paling rendah, diikuti oleh Structure and Written Expression, dan Reading Comprehension. Meskipun rata-rata ketiga bagian tersebut berbeda tapi kalau dikategorikan ke dalam table 2 . diatas , ketiga bagian tersebut memiliki kategori yang sama yaitu kategori adequate user yang artinya pengguna bahasa hanya mampu berkomunikasi yang sangat dasar sekali, itupun dengan bantuan lawan bicara.

\subsection{Listening Comprehension}

Berdasarkan data sebelumnya, jelas terlihat bahwa Listening Comprehension adalah bagian yang paling sulit karena memiliki rata-rata paling rendah dengan bagian yang lainnya. Listening Comprehension terdiri dari 3 skill yaitu short conversation, long conversation, and talking. Dari ketiga skill ini long conversation merupakan skill tersulit kemudian disusul oleh talking dan yang paling dianggap mudah adalah short conversation. Hal ini terlihat dari rata-rata mahasiswa dalam menjawab soal, dimana short conversation memiliki rata-rata 480, kemudian talking memiliki rata-rata 436, sedangkan long conversation conversation memiliki ratarata 410. Data ini tidak jauh berbeda dengan hasil wawancara, saat penulis bertanya ,"Skill manakah yang paling sulit kamu rasakan di bagian Listening Comprehensio?' Penulis mendapatkan jawaban bahwa $73.33 \%$ mahasiswa menjawab bahwa long conversation adalah skill paling sulit di bagian Listening Comprehension, 26.67\% mahasiswa menjawab bahwa talking merupakan skill yang paling sulit di 
bagian Listening Comprehension, dan 0\% mahasiswa menjawab bahwa short conversation merupakan skill yang paling sulit. Untuk lebih jelas, data tersebut akan digambarkan pada table berikut:

Table. 3. Nilai rata-rata mahasiswa di Listening Comprehension (hasil test diagnostik).

\begin{tabular}{|l|l|l|}
\hline NO & SKILL & $\begin{array}{l}\text { RATA } \\
\text { RATA }\end{array}$ \\
\hline 1 & Short Conversation & 480 \\
\hline 2 & Long Conversation & 410 \\
\hline 3 & Talking & 436 \\
\hline
\end{tabular}

Table. 4. Persentasi jawaban mahasiswa menentukan skill yang paling sulit di bagian Listening Comprehension (hasil wawancara)

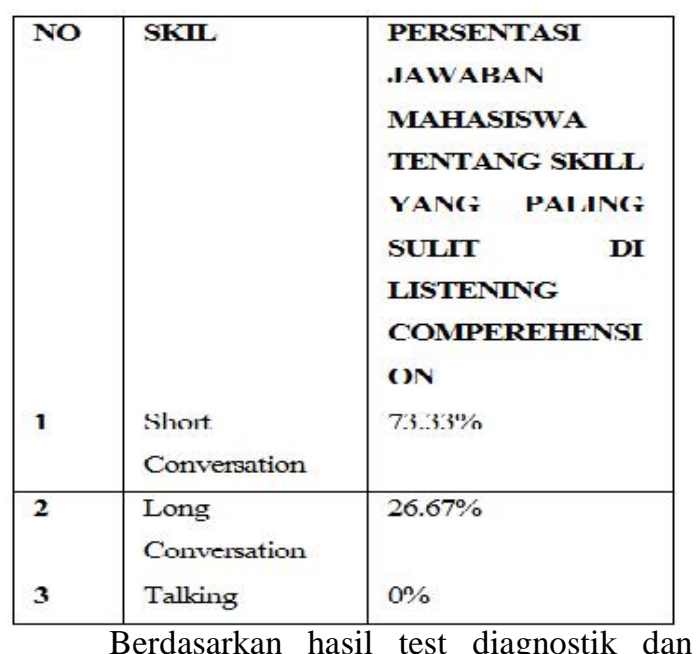
wawancara di atas, dapat disimpulkan bahwa kedua instrument memberikan jawaban yang sejalan. Hasil wawancara mendukung hasil test diagnostik, dimana long conversatioan merupakan skill yang paling sulit dihadapi mahasiswa pada bagian Listening Comprehension, kemudian disusul oleh talking, dan yang terahir adalah short conversation.

\subsection{Structure and Written Expression}

Bagian Structure and Written Expression adalah bagian kedua yang tersulit dirasakan mahasiswa saat mengahadapi TOEFL. Meskipun secara kuantitatif nilai Structure and Written Expression tidak jauh berbeda dari Listening Comprehension. Bagian Structure and Written Expression ini terdiri dari 2 skill yaitu Structure dan Written Expression.

Dari hasil test diagnostik, diperoleh data bahwa Written Expression lebih sulit dari Structure karena rata rata Written Expression adalah 453 dan rata -rata structure adalah 436. Hasil test disgnostik ini juga sejalan dengan hasil wawancara dimana $50.5 \%$ mahasiwa menjawab bahwa structure lebih sulit dari pada written expression, sedangkan sisanya sebanyak $49.5 \%$ mahasiswa menjawab bahwa written expression lebih sulit dari pada structure. Untuk lebih jelasnya, hasil kedua instrument dapat dilihat pada table berikut.
Table. 5. Nilai rata-rata mahasiswa di Structure and Written Expression (hasil test diagnostik)

\begin{tabular}{|l|l|l|}
\hline NO & SKIIL & $\begin{array}{l}\text { RATA - } \\
\text { RATA }\end{array}$ \\
\hline 1 & Structure & 453 \\
\hline 2 & Written Expression & 436 \\
\hline
\end{tabular}

Table. 6. Persentasi jawaban mahasiswa menentukan skill yang paling sulit di bagian Structure and Written Expression (hasil wawancara)

\begin{tabular}{|l|l|lr|} 
NO & SKILL & PERSENTASI \\
& & JAWABAN & \\
& & MAHASISWA & \\
& & TFNTANG & SKII I \\
& & YANG & PALING \\
& & SLLIT & DI \\
& & SIRUCIUKE & AND \\
& & WRITTEN & \\
& & EXPRESSION & \\
\hline 1 & Structure & $50.5 \%$ & \\
\hline 2 & Written & $49.5 \%$ \\
& Expression & & \\
\hline
\end{tabular}

Berdasarkan hasil test diagnostik dan wawancara di atas dapat disimpulkan bahwa hasil wawancara mendukung hasil test diagnostik, dimana written expression lebih sulit daripada structure saat menyelesaikan TOEFL.

\subsection{Reading Ccomprehension}

Reading Comprehension merupakan bagian ketiga dari TOEFL, di mana bagian ini terdiri dari 4 skill meliputi skill dalam mengidentifikasi topik, kalimat penjelas, mengidentifikasi kata - kata yang tidak dikenal, dan reference. Bagian ini merupakan hal paling mudah dirasakan mahasiswa saat menghadapi TOEFL, hal ini tergambar dari pengumpulan data melalui test diagnostik dan wawancara di mana bagian ini memperoleh rata-rata tertinggi dari bagian lainnya. Untuk lebih jelasnya dapat dilihat pada table berikut:

Table. 7. Nilai rata-rata mahasiswa di Reading Comprehension (hasil test diagnostik)

\begin{tabular}{|l|l|l|}
\hline NO & SKILI & $\begin{array}{l}\text { RATA } \\
\text { RATA }\end{array}$ \\
\hline 1 & Mengidentifikasi topic & 446 \\
\hline 2 & $\begin{array}{l}\text { Merıgiderıtifikasi kalimat } \\
\text { penjelas }\end{array}$ & 465 \\
\hline 3 & $\begin{array}{l}\text { Mengidentifikasi kata -kata } \\
\text { yang sulit }\end{array}$ & 421 \\
\hline 4 & Reference & 480 \\
\hline
\end{tabular}


yang paling sulit di bagian Reading Comprehension (hasil wawancara)

\begin{tabular}{|l|l|l|} 
NO & SKILL & $\begin{array}{l}\text { RATA } \\
\text { RATA }\end{array}$ \\
\hline 1 & Mengidentifikasi topic & $35 \%$ \\
\hline 2 & $\begin{array}{l}\text { Mengidentifikasi kalimat } \\
\text { penjelas }\end{array}$ & $10 \%$ \\
\hline 3 & $\begin{array}{l}\text { Mengidentifikasi kata-kata } \\
\text { yang sulit }\end{array}$ & $55 \%$ \\
\hline 4 & Reference & $0 \%$ \\
\hline
\end{tabular}

Hasil data dari test diagnostik dan wawancara terlihat jelas tidak ada perbedaan, dimana mengidentikfikasi kata-kata sulit merupakan skill tersulit. Hasil test diagnostik menunjukkan bahwa rata-rata dari skill ini adalah 421 dan rata- rata ini merupakan rata-rata terendah bila dibandingkan dengan skill lainnya di bagian reading comprehension. Hasil test diagnostik ini didukung oleh hasil wawancara dimana $55 \%$ mahasiswa mengatakan kalau mengidentiikasi kata- kata sulit adalah skill yang paling sulit di bagian reading comprehension.

Selanjutnya, mengidentifikasi topik merupakan skill kedua yang paling sulit dirasakan oleh mahasiswa di bagian Reading Comprehension. Hal ini tergambar dari hasil test diagnostik dan hasil wawancara. Dari hasil test diagnostik rata-rata menunjukkan 446 dan dari hasil wawancara $35 \%$ mahasiswa mengatakan kalau mengidentifikasi topik adalah skill yang paling sulit.

Setelah skill mengidentifikasi topik, skill mengidentifikasi kalimat penjelas merupakan skill ketiga yang paling sulit dirasakan oleh mahasiswa di bagian reading comprehension karena rata - rata skill ini adalah 465 dan hanya 10\% mahasiswa mengatakan kalau skill ini yang paling sulit.

Skill yang dinyatakan paling mudah adalah skill mengidentifikasi reference karena skill ini menunjukkan nilai rata -rata paling tinggi yaitu 480 dan secara wawancara respon mahasiswapun tidak ada yang mengatakn kalau reference adalah skill yang paling sulit.

\section{KESIMPULAN}

Berdasarkan data dan penjelasan sebelumnya, dapat diambil kesimpulan bahwa Listening Comprehension adalah bagian yang paling sulit dirasakan peserta saat menyelesaikan soal-soal TOEFL. Selanjutnya skill yang paling sulit dibagian Listening Comprehension secara berurutan adalah long conversation, talking, dan short conversation.

Bagian kedua yang paling sulit dirasakan mahasiswa saat menyelesaikan soal-soal TOEFL adalah Structure and Written Expression. Berdasarkan penjabaran di atas, jelas tergambar bahwa Structure lebih sulit dari pada Written
Expression.

Bagian yang paling mudah diantara tiga bagian TOEFL adalah Reading Comprehension, dimana pada bagian ini tergambar dengan jelas bahwa skill mengidentifikasi kata-kata sulit dinyatakan sebagai skill yang paling sulit di Reading Comprehension, kemudian mengidentifikasi topik, kalimat penjelas dan reference dianggap paling mudah.

\section{REFERENCES}

Creswell, Jhon. 2012, Education Research, fourth edition, Pearson, Boston

Dokumentasi UPT Bahasa Inggris Institut Pendidikan Bahasa Inggris 2018

Heni, Kartikasari. 2014. Analisis Regresi Multivariat Terhadap Penilian Listening, Structure, dan Reading pada Nilai Test EFL Mahasiswa ITS, http://ejurnal.its.ac.id/index.php/sains_seni /article/download/8111/2020

IELTS. (1999). Band Score. IELTS Handbook.

LAN, O. B. (1996). Language Centre Management Handbook. Jakarta: LAN.

SK Rektor Nomor 050/SK.K/STKIP-TS/I/10/2014 